\title{
Assessment of surface water chemistry and algal biodiversity in the Bay of Mostaganem and the Cheliff estuary: North-western Algeria
}

\author{
Fatima Kies
}

1- Department of the Environment and Earth, University of Milano Bicocca, Italy

Email: f.kies@campus.unimib.it

\begin{abstract}
Anthropogenic activities have led to water quality deterioration in many parts of the word, especially in Northwest Algeria. The current work investigated the spatiotemporal variations of water quality in the Cheliff River, samples for physico-chemical were performed at different periods from 2004 to 2007, the results chowed that nitrate $\left(\mathrm{NO}_{3}^{-}\right)$intake is very high especially in the month of February $2006(26 \mathrm{mg} / \mathrm{l})$ and February $2007(37 \mathrm{mg} / \mathrm{l})$, nitrite $\left(\mathrm{NO}_{2}{ }^{-}\right)$values also exceed the standard for samples taken at the estuary (and the sea), ie $0.96 \mathrm{mg} / \mathrm{l}$ in the month of February 2006 and $0.98 \mathrm{mg} / \mathrm{l}$ in April 2007; the Ammonium $\left(\mathrm{NH}_{4}{ }^{+}\right)$contributions are due to the River because the value recorded at the estuary (4.22 in February 2006) ; silicate $\left(\mathrm{SiO}_{2}\right)$ varies greatly depending on the River flow resulting from soil leaching SOUR to the estuary where we see the maximum values of $20.10 \mathrm{mg} / \mathrm{l}$ in the month of February 2007 and $19.1 \mathrm{mg} / \mathrm{l}$ in March 2005. The recorded values of elements phosphorus $\left(\mathrm{PO}_{4}^{--}\right)$are high and very variable from 0.01 to $1.90 \mathrm{mg} / \mathrm{l}$ for the River, $0.01-0.80 \mathrm{mg} / \mathrm{l}$ for the estuary and $0-0.49 \mathrm{mg} / \mathrm{l}$ for the sea. The analyzed biological confirmed a total of 41 phytoplankton speciesand31 macroalgae species. So, Aquatic ecosystems are particulury vulnerable to environmental change and many are, at present, severely degraded.
\end{abstract}

Keywords:Eutrophication, phytoplankton blooms, nitrates, phosphates, marine pollution.

Introduction

Deterioration of water quality has induced serious environmental and ecological problems in Rivers in the word, e.g., Rivers of Algeria (Gagneur and Kara. 2001, Belhadj. 2001, Grimes et al. 2003, AlAsadi et al. 2005, Kies and Taibi. 2011, Kies et al. 2012, Hamaidi-Chergui et al. 2013, Kies and Kerfouf. 2014 a,b), Rivers of Italia (Bonzini et al.2008), Rivers of Spain (Alvarez-Vazquez et al., 2008), Rivers of China (Le Thi et al. 2009, Wang et al. 2013, Bu et al. 2014, Huang and Lu. 2014, Gao et al. 2014), River of United States of America (Woodbury et al. 2008, Graney et al. 2008), Rivers of India (Shachi Shekhar et al. 2006, Pandey et al. 2014), Rivers of Russia (Rusanov and Stanislavskaya. 2009), Rivers of Malaysia (Al-Badaii and Shuhaimi-Othman. 2014). 
Scientific monitoring showed the influence of the Cheliff River on the marine ecosystem, including negative effects on phytoplankton that presents a real disturbance about its abundance (Grimes et al. 2003,Al-Asadi et al. 2005, Kies and Taibi. 2011, Kies et al. 2012, Kies and Kerfouf. 2014a), and the effects on macroalgae (Kies and Taibi. 2011). To identify cases of coastal eutrophication (Kies and Taibi. 2011, Kies et al. 2012, Kies and Kerfouf. 2014a) and propose methods of supervision as to reduce these phenomena, it is first necessary to retain rather the notion of enriched state to such an extent that results in harm to the ecosystem, and thus for humans. Based on the average chemical equations for the synthesis and degradation of organic matter in the sea (Bougis. 1974, Aminot andChausspied. 1983, Billen and Garnier. 2007, Garnier et al. 2008, Hamaidi-Chergui et al.2013, Kies and Kerfouf. 2014a,b), this operational definition thus favors the adverse effects of enrichment, that is to say the production of algal biomass excessive or unbalanced in terms biodiversity (Persson. 1976, Woodbury et al. 2008, Graney et al. 2008, Kies and Taibi. 2011, Hamaidi-Chergui et al. 2013, Kies et al. 2012) and more or less severe hypoxia resulting from the degradation of this excess organic matter. On the other hand, the depreciation of the quality of the marine environment leads to the unsustainability of our marine ecosystem (environmental side) which leads to the loss of several possibilities of exploitation of our coastlinein terms of tourism projects, fishing and aquaculture... etc (economic side) at the same time it affects the health of human beings and their well being (sociological side) (Woodbury et al. 2008, Graney et al. 2008, Kies et al. 2012, Hamaidi-Chergui et al. 2013). We believe that cross-linking between hydrologiy, chimistry and ecology is essential for the holistic understanding of pollution input, processing, and export at the watershed scale (Graney et al. 2008) and the sea water (Rodier. 1996, Sigg et al. 2000, Ramade. 2000, Kies and Taibi. 2011,Kies et al. 2012).

\section{Materials and methods}

\section{Characterization of coastal ecosystems Mostaganem}

Biological parameters : many inventory studies have been conducted to accurately determine the different flora and fauna species of the coast. Therefore, until the moment there is no information on the distribution and abundance of species in the coastal region of Mostaganem (Kies and Taibi. 2011,Kies et al. 2012, Kies and Kerfouf. 2014a).

Geomorphology of the coast Coastal forms of the wilaya of Mostaganem are expressed by the existence of large and beautiful open beaches, especially around the estuaries regions (The Cheliff Riverand MactaaRiver). The geomorphological aspects is reflected by the presence of cliffs, higher or lower, subject to marine erosion, thus contributing to food neighboring beaches. Marine processes, the most influential is the hydrodynamics, accelerating erosion in areas of high concentration of marine energy and promotes accumulation in less agitated sites (Kies and Taibi. 2011, Kies et al. 2012). The combination of various morphogenetic factors (tectonics, lithology, hydrodynamics) generated the 
most important forms and formations (Kies and Taibi. 2011). The 124 kilometers of coastline are largely made up of rocky relief, more or less steep drop compared to sea level. Rocky shores are more common in the West and the East (Kies and Taibi. 2011, Kies et al. 2012, Kies and Kerfouf. 2014a). They are most noticeable in the western part of the coast of Mostaganem (Kies and Taibi. 2011). They pale in against the benefit of sea cliff to the east coast, fueled in particular by contributions from Rivers « Cheliff and others ». The Mostaganem continental margin varies both by its size and by its form. To the west, the continental shelf is relatively wide, with gentle slopes. To the east, there is a slight increase in the slope. The coast of Mostaganem is affected by wind erosion, this erosion results from an imbalance in the dynamic interactions between the "climate", the "soil", the "vegetation" and "man" (Kies and Taibi. 2011, Kies et al. 2012). The lands that form the coast are very unstable because of their sensitivity to water and wind erosion.

Cheliff River is the largest River of Algeria. It depends on the Mediterranean, extends over a distance of $800 \mathrm{~km}$ and covers an area of $43,750 \mathrm{~km}^{2}$. Its starting point is in the Saharan Atlas at Djebel Amour. Cheliff River (Bouzelboudjen and Mania. 1989, Belhadj. 2001, Kies and Taibi. 2011, Kies et al. 2012, Kies and Kerfouf. 2014b) is limited to the north by the Mediterranean Sea, to the south by the Sahara to the west of Oran and east by the Algiers region (Fig. 01). The hydrographic network of Cheliff River is fed by several tributaries and groundwater. The monthly and annual flow regime of the Cheliff River is extremely irregular. In general, the fluid intake of Cheliff River is important from September to May and almost negligible during the summer (Kies and Taibi. 2011, Kies et al. 2012, Kies and Kerfouf. 2014b).A statistical approch on the 1968-1985 period shows total precipitations of $420 \mathrm{~mm}$ (maximum in February and minimum in July-August whith $75 \mathrm{~mm}$ ), an interannual avrage temperature of $18.5^{\circ} \mathrm{C}$ and potentiel evapotranspiration of $385 \mathrm{~mm}$ (Bouzelboudjen and Mania. 1989).

The estuary is the end portion of the lower course of the River water at which it flows into the sea by providing significant amounts of sand, mud and pebbles. In this area, the decrease in velocity and the density difference between freshwater and seawater are as the sands and silts in suspension settle. According to the observation made in the field, the key deposit of the estuary mud. Species may belong to one or other of ecosystems we meet (River / Sea). The estuary is a biotope with high biological productivity; laden waters of mineral nutrients thus have a eutrophic character marked. The ecosystem that characterizes the estuary area is important for many species of migratory fish anadromous like the wolf or catadromous as eel.

Laboratory procedures: these were determined by the methods mentioned or approved by AFNOR by Rodier. (1996). Sampling: washing of the sampling equipment before each use; marking of sampling equipment by the number of the station that must refer to the specifications of the station; temperature measurement in-situ; bottle rinsing with water to be taken before each sample is required; opening bottles under the water surface to prevent any contamination of the specimen. To preserve our samples, we must add the reactants immediately after filling the sample bottle such that $(3 \mathrm{ml}$ of 
Sustainability, Agri, Food and Environmental Research 3(1), 2015: 1-16 ISSN: 0719-3726

magnesium carbonate (hydroxycarbonate) $\rightarrow 1 \%$ for the chlorophyll a; $1 \mathrm{ml}$ of manganese sulfate (reagent 1 ) and $1 \mathrm{ml}$ of potassium iodide (Reagent 2) $\rightarrow$ for the dissolved oxygen. A few drops of formalin $\rightarrow$ for the phytoplankton.

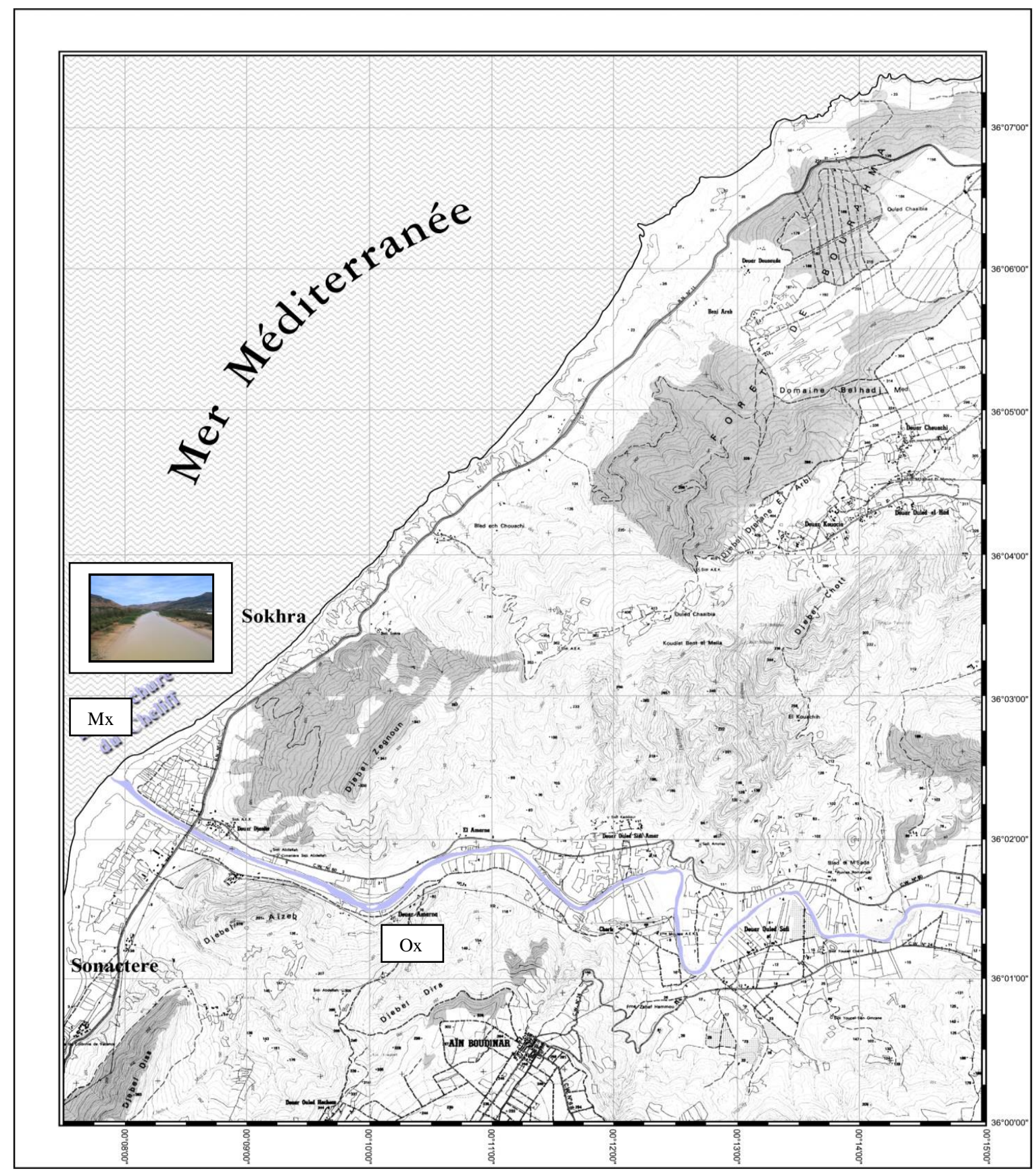

Figure 1: Sidi Ali map with the Cheliff River (colored blue) and the beaches of Sonactere and Sokhra (Kies \& Taibi, 2011).

The samples were taken at various stations that have been selected based on their distance from the mouth of the Cheliff River; that is to say at a distance from the latter. The position of the different samples is shown on the figure 01 by "Mx" for the samples taken from the sea and "Ox" for 
those taken from the River. Samples "Mx" for physico-chemical and hydrobiological were performed at different periods of 2004 and 2007.

Packaging and transport of samples: are carried in a portable cooler with sufficient reserve cold, especially during hot weather. Therefore, a temperature of $4^{\circ} \mathrm{C}$ is suitable for the storage of short duration (a few hours to a few days); beyond, it is best to use freezing (Rodier, 1996).

Physico-chemical analysis of water: In the search for environmental factors that may play a role limiting factor in the development of organisms, we measured some soil physicochemical factorssuch as type:Inorganic nutrients:Nitrogen compounds: Nitrate $\left(\mathrm{NO}_{3}{ }^{-}\right)$, nitrites $\left(\mathrm{NO}_{2}{ }^{-}\right)$, ammonium $\left(\mathrm{NH}_{4}^{+}\right)$,Phosphorus compounds: Ortho phosphates $\left(\mathrm{PO}_{4}^{--}\right)$, Sulfur compounds: Sulfates $\left(\mathrm{SO}_{4}^{-}\right)$, Silicon: Ortho silicate $\left(\mathrm{SiO}_{2}\right)$. Hydrobiological analyzes are intended to determine the quantitative composition of stands of various organisms to clean inland aquatic biocoenoses. We measured some water Hydro biological factors such as type: Chlorophyll (a), Phytoplankton, Macro algae.

\section{Results and Discussion}

The results of physicochemical analyzes of water of the Cheliff River(SOUR AND SIDI BELATAR) and seawater (since Sokhra east of the estuary of the Cheliff River 2500m up to Sonactere west of Cheliff River2500 m) are mentioned in the Table.1 (a, b) and Figure.02.

The results of physico-chemical and biological analyzes presented here mainly concern the ecosystem «freshwater and saltwater». The study focused primarily on eutrophication parameters are phytoplankton is the first link in the food chain, by measuring chlorophyll a relative to continental inputs of nutrients.

Nitrate (NO3):Intake is very high. The recorded values exceed the standards $(0.003 \mathrm{mg} / \mathrm{l})$ and suggest a soil leaching which led to the enrichment of the Cheliff River nitrate especially in the month of February 2006 (26 mg/l) and February 2007 (37 mg/l). In February 2007, the concentration reaches $23 \mathrm{mg} / \mathrm{l}$ at the mouth, $24 \mathrm{mg} / \mathrm{l}$ in the West and $6 \mathrm{mg} / \mathrm{l}$ in the east of the mouth. Therefore, consumption of nitrogen as nitrate is activated eastward than westward and, throughout the study period (20042007).

Nitrite $\left(\mathrm{NO}_{2}\right)$ : As for nitrates, nitrites values also exceed the standard $(0.002 \mathrm{mg} / \mathrm{l})$ for samples taken at the mouth (and the sea), ie $0.96 \mathrm{mg} / \mathrm{l}$ in the month February 2006 and $0.98 \mathrm{mg} / \mathrm{l}$ in April 2007. To the west of the mouth and in the same period, the concentrations of nitrites are $0,50 \mathrm{mg} / \mathrm{l}$ and 0.01 $\mathrm{mg} / \mathrm{l}$. In the East, they reach successively $0.5 \mathrm{mg} / \mathrm{l}$ and $0 \mathrm{mg} / \mathrm{l}$. It should be noted that the exhaustion of nitrites in March and April 2007, is due to the evolution of nitrogen compounds (ammonification: NH4 NO2) therefore, it can be deduced that it is an index of pollution.

Ammonium $\left(\mathrm{NH}_{4}^{+}\right)$:Contributions are due to the River because the value recorded at the mouth (4.22 in February 2006) is a sample taken 20 m downstream of the River, so in seawater. In 
February 2006, the contributions valued at $4.22 \mathrm{mg} / \mathrm{l}$ (maximum value exceeding the standard 0.003 $\mathrm{mg} / \mathrm{l}$ ) reaching west to a value of $1.58 \mathrm{mg} / \mathrm{l}$. Note ammonium exhaustion at the mouth in April 2006 because the nitrate intake was low (dry period). From March 2005 to March 2006 with the advent of spring bloom and flow reduction and the contribution of the River ammonium, one notices the depletion of this ion in the East as well as west of the mouth, while in April and February of 2005 and 2006, this occurs only in the East of the mouth.

Elements phosphorus $\left(\mathrm{PO}_{4}^{--}\right)$:The evolution of the concentrations of phosphates during the study period is shown in Table 1 and Figure 2. The recorded values are high and very variable: from 0.01 to $1.90 \mathrm{mg} / \mathrm{l}$ for the River, $0.01-0.80 \mathrm{mg} / \mathrm{l}$ for the mouth and $0-0.49 \mathrm{mg} / \mathrm{l}$ for the sea. These values vary depending on the flow of the River and soil leaching, they are high when the flow is strong and they reach their minimum when it is low. In February 2007, the concentrations of phosphates are the highest, $0.90 \mathrm{mg} / \mathrm{l}$ in the waters of the River, $0.80 \mathrm{mg} / \mathrm{l}$ at the mouth and $0.20 \mathrm{mg} / \mathrm{l}$ in the west the mouth. To the east by against the values recorded $0.05 \mathrm{mg} / \mathrm{l}$ are relatively low; these values $0-0.01$ mg/l also appear in March 2007 when the flow of the River was quite low. The concentration of phosphate decreases until the completion of this ion to the east and to the west of the mouth, in the case of March 2005, February and April 2006, and March 2007.

Silicates $\left(\mathrm{SiO}_{2}\right)$ : silicate varies greatly depending on the River flow resulting from soil leaching SOUR to the mouth where we see the maximum values of $12.2 \mathrm{mg} / \mathrm{l}$ in March 2004, 19.1mg/l in March 2005, 18.20 mg/l in February 2006 and $20.10 \mathrm{mg} / \mathrm{l}$ in the month of February 2007. Depletion of silicates West and East from the mouth is about 0 mg/l in March 2004 February March 2005 and March 2007, and is due to the consumption by the phytoplankton. The annual flow of dissolved inorganic nitrogen and silicate is significantly higher in the period followed the flow of the River: 2004 - 2007, showing the importance of soil leaching for these two nutrients. The flow of phosphate, however, remained relatively stable.

Degree of eutrophication (E):For each sample, the concentration unit of nitrogen and phosphate elements measured in $\mathrm{mg} / \mathrm{l}$, are then transformed into $\mu \mathrm{mol} / \mathrm{l}$ (molarity). Depending on the scale of the trophic index, we can classify our River is "Eutrophic" because the degree of eutrophication «E» is less than 1.60. It is equal to 1.37 for the Cheliff River and 1.57 for seawater (Table 2).

Nutrients and phytoplankton: The first step of the food chain, phytoplankton growth is conditioned by the presence of nutrients, mainly nitrogen and phosphorus needed for all species, but silicon, essential for siliceous skeletal algae such as diatoms.

In these coastal, terrestrial inputs can significantly enrich the environment in nitrogen and phosphorus (industrial, urban and agricultural). Excessive enrichment of one or more elements may then affect the balance and density of natural populations. Bay Mostaganem shows an example of the coastal area influenced by major continental contributions. It was therefore interesting to know the distribution of different nutrients to several times of the year. We mainly focusing in mineral nutrients 
in dissolved form, representing the majority of chemical species available for phytoplankton. We will examine the influence of fresh water (Cheliff River) on the Mostaganem Bay by studying their dilution (Tables 1 and 2).

Table 1: Comparison of nutrients $(\mathrm{N}, \mathrm{P}, \mathrm{Si}$ ) in the freshwater (Cheliff River) and estuarine water expressed in $\mu \mathrm{mol} / \mathrm{l}$. FW: freshwater; TOT: total estuary water and sea water.

\begin{tabular}{cccccccc}
\hline \multirow{2}{*}{ Year } & & \multicolumn{2}{c}{$\mathrm{N}$} & \multicolumn{2}{c}{$\mathrm{P}$} & \multicolumn{2}{c}{ Si } \\
& Month & FW & TOT & FW & TOT & FW & TOT \\
& February & 1003.24 & 292.86 & 5.05 & 0.63 & 26.66 & 163.33 \\
& March & 436.63 & 759 & 6.21 & 1.57 & 211.66 & 220 \\
& April & 479.09 & 644.27 & 11.47 & 11.36 & 71.66 & 76.66 \\
& February & 551.03 & 222.44 & 3.47 & 5.15 & 243.33 & 106.66 \\
& March & 601.27 & 513.95 & 3.78 & 0.52 & 395 & 391.66 \\
& April & 733.54 & 163.05 & 10.63 & 2.63 & 25.66 & 50 \\
& February & 1551.1 & 897.07 & 2.63 & 0.31 & 340 & 386.66 \\
& March & 630.37 & 367.79 & 9.15 & 5.78 & 421.66 & 251.66 \\
& April & 176.86 & 306.25 & 0.1 & 0.21 & 56.66 & 33.33 \\
& February & 2054.49 & 1226.56 & 26.63 & 11.05 & 415 & 406.83 \\
& March & 458.03 & 335.1 & 1.78 & 0.1 & 238.33 & 48.33 \\
& April & 862.47 & 587.14 & 5.26 & 4.31 & 340 & 113.33 \\
\hline
\end{tabular}

The enrichment of water by nutrients has resulted in significant increase in phytoplankton stocks at the mouth of Cheliff (Mostaganem Bay). In the future, it would be interesting to extend the study to see if the concentrations of phytoplankton will increase despite the significant contribution of nutrients.

The study of the molar ratio of the concentrations of dissolved inorganic nitrogen and phosphate shows that within the estuary this report is to high values of flood between 198.51 and 249.38 upstream swallows these high values during the studied periods are mainly due to the importance of Riverine inputs of nitrate. All these values tends to rise as within the estuary and especially to the west, reports remains high and reflect a clear influence of the water quality of the watershed on the characteristics of estuarine waters, in Regarding the balance of nitrogen and phosphorus salts.

Table. 2: ratio comparison (N/P and $\mathrm{N} / \mathrm{Si}$ ) of nutrients $(\mathrm{N}, \mathrm{P}, \mathrm{Si})$ in freshwater and estuarine water expressed in $\mu \mathrm{mol} / \mathrm{l}$. FW: freshwater; TOT: total mouth water $\&$ sea water. 
Sustainability, Agri, Food and Environmental Research 3(1), 2015: 1-16

ISSN: 0719-3726

a. River water Cheliff (2004/2007)

\begin{tabular}{lccccc}
\hline Parameters & 2004 & 2005 & 2006 & 2007 & $2004 / 2007$ \\
\multicolumn{1}{c}{ Years } & & & & & \\
\multicolumn{1}{c}{} & & & & & \\
\hline $\mathrm{N}$ (NID) & 1918.96 & 1885.84 & 2358.33 & 3374.99 & 9538.12 \\
$\mathrm{P}$ & 22.73 & 17.93 & 11.88 & 33.67 & 86.21 \\
$\mathrm{Si}$ & 309.98 & 663.99 & 818.32 & 993.33 & 2785.62 \\
(N) Nb of samples & 6 & 6 & 5 & 6 & 23 \\
E (degree of & 2.64 & 2.86 & 3.68 & 2.81 & 1.57 \\
eutrophication) & & & & 100.23 & 110.63 \\
$\mathrm{~N} / \mathrm{P}$ & 84.42 & 105.17 & 198.51 & 3.39 & 3.42 \\
\hline $\mathrm{N} / \mathrm{Si}$ & 6.19 & 2.84 & 2.88 & & \\
\hline
\end{tabular}

b. Seawater $(2004 / 2007)$

\begin{tabular}{lccccc}
\hline Parameters & 2004 & 2005 & 2006 & 2007 & $2004 / 2007$ \\
& & & & & \\
\multicolumn{1}{c}{ Years } & & & & & \\
\hline $\mathrm{N}$ (NID) & 1696.13 & 899.44 & 1571.11 & 2148.8 & 6315.48 \\
$\mathrm{P}$ & 13.57 & 8.3 & 6.3 & 15.46 & 43.63 \\
$\mathrm{Si}$ & 459.99 & 548.32 & 671.65 & 568.49 & 2248.45 \\
(N) Nb of samples & 9 & 9 & 9 & 9 & 36 \\
$\mathrm{E}$ (degree of & 2.63 & 2.48 & 3.32 & 2.73 & 1.39 \\
eutrophication) & 124.99 & 108.36 & 249.38 & 138.99 & 144.75 \\
$\mathrm{~N} / \mathrm{P}$ & 3.68 & 1.64 & 2.33 & 3.77 & 2.8 \\
\hline $\mathrm{N} / \mathrm{Si}$ & & & & \\
\hline
\end{tabular}

These high values of N / P ratio, compared with the optimal theoretical value of 16 (compared Rield Field) for phytoplankton growth tended to rise as it may be limited in the estuary by phosphorus; however, the phosphorus concentrations in the estuary never fall to sufficiently low values to be limiting.

The indicators of eutrophication

Oxygen : In natural waters, the physical laws are not the only ones involved. The biological processes involved in oxygen consumption resulting from said heterotrophic process and / or production of oxygen resulting from autotrophic process (plant photosynthesis). The differences in saturation can be highlighted so practice by calculating the percentage of oxygen relative to the saturation $(\%$ Sat O2): Oxygen Saturation Percentage $=($ Measured concentration $/$ Saturation $) \times 100$ This quantity expresses the result of heterotrophic and autotrophic processes. Under certain conditions, there may be a higher oxygen concentration to the saturation (saturation percentage greater than 100 
for example in our case study we found a maximum saturation value in River water which is Cheliff 173.5, and that in April 2006), it is called saturation. Only the photosynthesis of submerged plants (macrophytes, micro algae, plankton, benthic) is capable of driving significant on-saturations. As we found minimal values of oxygen saturation, 22.40 and 40.30 in Cheliff River in seawater and this is due to the degradation aquatic flora.

Floristic composition: Fixing criteria for changes in phytoplankton composition and concentrations of harmful phytoplankton species is not easy because some species give rise to developments in mass (case Phaeocystis), while others may have adverse effects at lower concentrations (case Dinophysis and Alexandrium). Finally some cases harmful dinoflagellate developments are not related to eutrophication. As part of the protection of public health, we must establish relationships between cellular concentrations of harmful phytoplankton species and toxicity thresholds (Table 3).

Biodiversity of macro algae :

In the mechanisms accompanying the evolution of an ecosystem of a young and unstable towards a sustainable equilibrium or climax (succession), species richness tends to increase and become more complex trophic links (parasitism symbiosis). Against the possibilities of feedback between populations increase, strengthening the stability of the environment. Thus, the biological communities developing in stable environments will always have a higher species diversity than those exposed to human disturbance. In response to strong eutrophication imbalance the ecosystem, there will be a regression type of climax species (perennial slow-growing algae and seagrasses, replaced by opportunistic species most competitive in highly enriched environment. The various processes that can be direct as a competition for the acquisition of nutrients and light energy, the competition is moving from the first to the second when the degree of eutrophication increases. Indirect processes tend to accelerate the phenomenon. Depopulation perennial crops facilitates resuspension of sediment and turbidity of the water, they are more sensitive than phytoplankton. On the other hand, the blooms can be followed by anoxic crises at the bottom sediment and water, which them- same favor the release of nutrients of sedimentary origin. Thus the progress of eutrophication is not linear, but present jumps from one state to another. The evolution of the main components of an ecosystem in the eutrophication status progresses. In this increasing gradient, nutrient availability and water turbidity increase together. In the first stage of eutrophication, perennial benthic macrophytes fell sharply while phytoplankton and macro opportunistic algae populations are increasing, and epiphytes "explode". In the second stage, the epiphytic collapse in turn, and perennial algae disappeared. Drift macroalgae and / or phytoplankton proliferate while. At the final stage, phytoplankton thrives only, opportunistic macroalgae disappearing in turn. Macro algal blooms are done opportunistic species including green algae of the genera Chaetomorpha, Cladophora, Enteromorpha and Ulva above. AtMostaganem coast macro algal proliferation issues are briefly summarized in Table 4.

The report rodophytes / pheophytes (R / P) J.Feldmann 1937 
Sustainability, Agri, Food and Environmental Research 3(1), 2015: 1-16

ISSN: 0719-3726

$\mathrm{R} / \mathrm{P}=$ total dominance of algae Rodophycaées / sum of the dominance of algae Phéophycaées

Table 3 .List of phytoplankton species found in the study area

\begin{tabular}{|c|c|}
\hline Chrysophyta & Chlorophyta \\
\hline Nitzschia acicularis & Pediastrum simplex \\
\hline Nitzschia sigma & Pediastrum duplex \\
\hline Melosira granulata & Pediastrum $\mathrm{sp}$ \\
\hline Navicula sp & Tetraedron minimum \\
\hline Navicula cuspidata & Staurastrum sebaldi \\
\hline Navicula confervacea & Staurastrum orbiculare \\
\hline Navicula subtilissinae & Scenedesmus acuminatus \\
\hline Gyrosigma balticum & Scenedesmus flexиosis \\
\hline \multirow[t]{2}{*}{ Cyclotelle meneghiana } & Scenedesmus javanensis \\
\hline & Scenedesmus quadricauda \\
\hline Euglenophyta & Closterium limneticum \\
\hline Euglena sp. & Closterium acutum \\
\hline Euglena variabilis & Coelastrum microsporum \\
\hline Trachelomonas armata & Dictyococcus varians \\
\hline \multirow[t]{5}{*}{ Trachelomonas megalacantha } & Oocystis crassa \\
\hline & Cosmarium granatum \\
\hline & Chlamidomonas sp. \\
\hline & Monoraphidium contortum \\
\hline & Strombomonas sp. \\
\hline Pyrrhophyta & Cyanophyta \\
\hline Peridinium sp. & Microcystis sp. \\
\hline Peridinium volzii & Microcystis elaschista \\
\hline Diplopsalis acuta & Oscillatoria subsalsa \\
\hline \multirow[t]{2}{*}{ Ceratium herundinella } & Oscillatoria tenuis \\
\hline & Nostocopsis lobatus \\
\hline
\end{tabular}




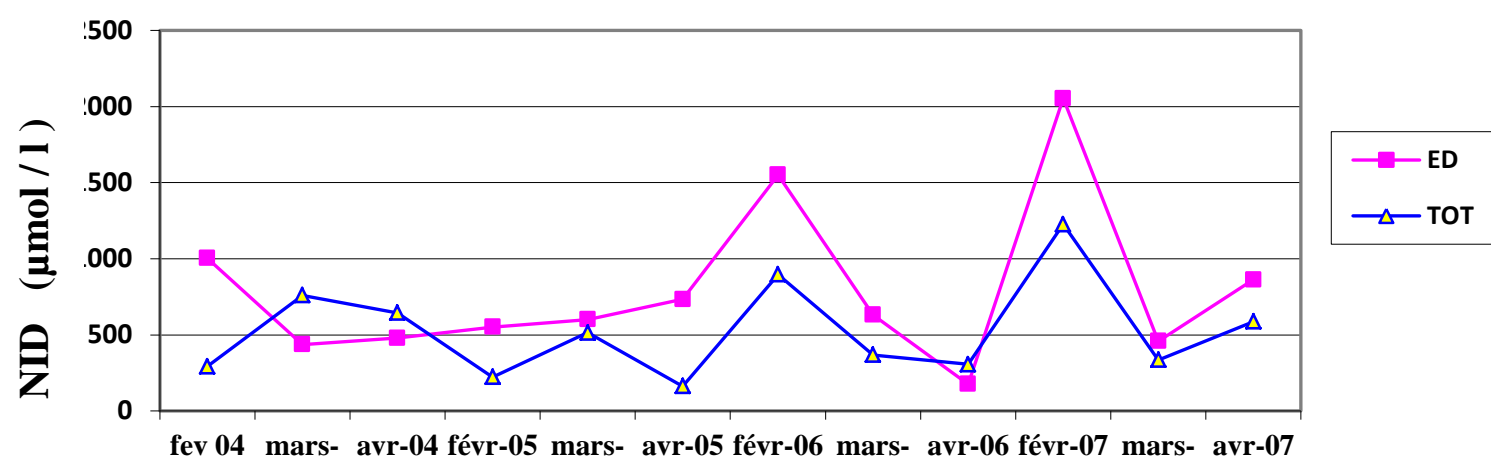

04

05

06

07
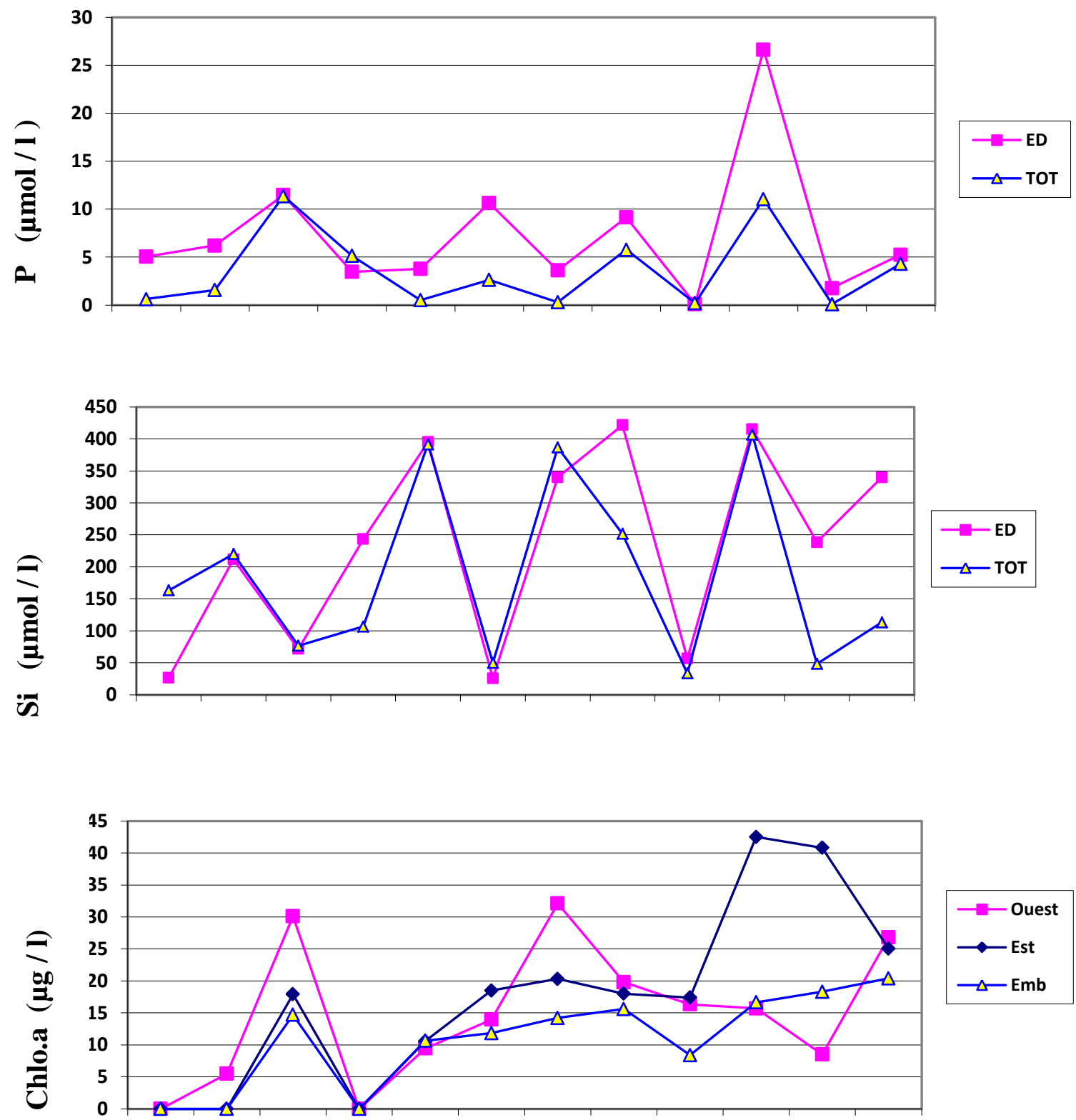

Figure 2: Nutrients in surface water of Cheliff river, stuary and freshwater 
Sustainability, Agri, Food and Environmental Research 3(1), 2015: 1-16

ISSN: 0719-3726

Table 4. Main event of macro algal proliferation in Mostaganem

Species encountered

Report R/P

Zone

\begin{tabular}{|c|c|c|c|c|}
\hline & Brown algae & Red algae & Green algae & \\
\hline & -Dillophus faxolla & -Jania rubens & -Eteromorpha linza & \\
\hline & -Culteria multifida & -Rhodothameniella floridula & -Blidingia minima & \\
\hline & -Sargassum mutucum & -Phyllophora & -Ulva lactuca & $\mathrm{R} / \mathrm{P}$ ratio lower \\
\hline & -Fuccus serratum & pseduceranoides & -Cladophora lactervires & than 3: slightly \\
\hline & -Cystoseira stricta & -Plumaria elegans & -Enteromorpha sp & polluted area \\
\hline & -Cystoseira foniculeca & -Peyssonnelia & & \\
\hline & -Cystoseira sarggearniana & -Gloisiphoni acipilloras & & \\
\hline \multirow[t]{5}{*}{ Sokhra } & -Cystoseira barbata & -Vangilia & & $3 / 4=0.75$ \\
\hline & -Ectocarpus siliculosus & -Coralina elonoida & & \\
\hline & -Taunia atomoria & & & \\
\hline & -Padina pavonica & & & \\
\hline & & Species encountered & & Report R/P \\
\hline \multirow[t]{8}{*}{ Zone } & Brown algae & Red algae & Green algae & \\
\hline & -Sargassum vulgare & -Jania rubens & -Eteromorpha linza & \\
\hline & -Nemalion feliformis & -Rhodothameniella floridula & -Ulva lactuca & \\
\hline & -Colpominia sinusa & -Plumaria elegans & -Blidingia minima & \\
\hline & -Padina pavonica & -Callithamnion tedvirens & -Cladophora lactervires & \\
\hline & -Halopitrise seoparia & -Wrangeli jenecillata & -Codium fragile & $\mathrm{R} / \mathrm{P}$ greater \\
\hline & -Cutlria multifida & & & than 3: highly \\
\hline & -Fuccus virsoides & & & polluted area \\
\hline \multirow[t]{3}{*}{ Sonactere } & -Cystoseira stricta & & & \\
\hline & -Phillariobrevipes & & & \\
\hline & & & & $4 / 1=4$ \\
\hline
\end{tabular}

Nutrients richeness :

One must consider that in the background coastal environment occurs, first as a place of remineralization of nutrients, on the other hand as a deposit area and resuspension of fine and sparse charged particles of nutrients. If the depth does not exceed a few tens of meters, vertical and horizontal currents redistribute remineralized elements in the water column. The hydrodynamics of the area is a significant factor in the handover of vis-à-vis nutrient species growing in the water column. However, the hydrodynamics may also contribute to the dispersion, thus at a certain phase, enriched nutrient patches. This is important when considering the developments of micro and macro algae. Some questions concerning nutrients may be asked; can we define a nutrient concentration threshold (or a function that concentration criterion) at which a system can be considered eutrophic (nutrient rich)? 
All eutrophic system is there a potential for eutrophication system? Is there a nutrient concentration threshold beyond which a system is at risk of eutrophication? Is there a nutrient concentration threshold beyond which a system can be considered eutrophic? If such a threshold could be defined, it would be the same regardless of the particular site? Does it take into account the concept of flows, and if so, on what basis?

This succinct approach was to show that the definition of nutrient-based criteria can be very difficult given the other factors controlling algal growth. The consequences of the enrichment of the aquatic environment, particularly in coastal areas, are multifactorial effect (biological, chemical, physical) and can not be predicted with certainty or inflected by reference to a (or several) test (s) simplifier ( $\mathrm{s}$ ) based (s) on a nutrient concentration. Depending on the definition of eutrophication, that is to say, the state of a medium enriched with nutrients such as to cause damage to the environment or nuisance to use, so it can appear more effective to focus the assessment of the eutrophication status of a zone on criteria related to symptoms in preference to criteria related to potential triggers. Symptoms can be identified, for example, high concentrations of chlorophyll, growth of epiphytes and macroalgae, changing algal dominance (diatomaceous/flagellates), the appearance of toxic species, decomposition of biomass, the phenomenon of anoxia.

\section{Conclusion}

The results of the physico-chemical and hydrobiological water from River, sea and estuary during flood periods showed that Cheliff pours a considerable amount of pollutants in the River mouth area. Polluted waters issued by the nine wilayas of the country are channeled by Cheliff River to empty into the Bay of Mostaganem. The pollutants are industrial, urban and agricultural. The study revealed the presence of nitrogenous substances, phosphorus and sulfur. According to the scientific monitoring carried out between October 2004 and April 2007, the detected pollutants have negative consequences on the marine fauna and flora of the Bay of Mostaganem, particularly in the area of the mouth of Cheliff. Because of winds east and coastal ocean currents that result, polluted water head in times of flooding to the west coast and can sometimes reach the beach Sablettes (December 2004 where rainfall reached $146.5 \mathrm{~mm}$ ). The huge amounts of solid particles in the water prevent the penetration of sunlight, for this, the development of the flora is reduced to a minimum in the area of the mouth as confirmed by observation of immersions marine benthos.

\section{References}

Al-Asadi, M. S., P. Randerson, \& K. Benson-Evans, 2005. Phytoplankton population dynamics in three West Algerian rivers: III. The Tafna River and its tributary the Remshy River.Marina Mesopotamica Online 1(1): 73. 
Al-Badaii, F., \& M. Shuhaimi-Othman, 2014.The impact of Anthropogenic Pollution and Urban Runoff Associated with Spatial and Seasonal Variation on the Water Quality in the Semenyih River, Malaysia.World Applied Sciences Journal. 32: 1061-1073.

Alvarez-Vazquez, L.J., A. Martinez, M.E. Vazquez-Mendez, \& M.A. Vilar, 2008. An Application of optimal control theory to river pollution remediation. Applied Numerical Mathematics. 59: 845-858.

Aminot, A., \& M. Chausspied, 1983. Manuel des analyses chimiques en milieu marin, Centre National pour l'Exploitation des Océans (CNEXO).

Belhadj, M., 2001. Etude de la pollution des eaux du bassin de Chéliff et son impact sur l'environnement. Mémoire de Magister en Chimie de l'Environnement, Faculté des Sciences de l'ingénieur, Université de Mostaganem, Algérie.

Billen, G., \& L. Garnier, 2007. River basin nutrient delivery to the coastal sea: assessing its potential to sustain new production of non-siliceous algae. Marine Chemistry. 106, 148-160.

Bonzini, S., A . Finizio, E. Berra, E., Forcella, M., P. Parenti, \& M. Vighi, 2008. Effects of river pollution on the colonisation of artificial substrates by macrozoobenthos. Aquatic Toxicologie. 89, 110.

Bougis P., 1974. Ecologie du plancton marin. Le phytoplancton, Tome 1, Masson et Cie, Paris VI.

Bouzelboudjen, M., \& J. Mania, 1989. Hydrogiology of the middle Cheliff Basin (Algeria) Simulation of the groundwater flows, International workshop on appropriate methodologies for development and management of groundwater ressources in developing countries Hyderabad, India, Vol 2: 505-521.

Bu, H., W. Meng, \& Y. Zhang, 2014. Spatial and seasonal characteristics of river water chemistry in the Taizi River in Northeast China. Environmental Monitoring Assessment 186, 3619-3632.

Gagueur, J., \& H. Kara, 2001.Limnology in Algeria.In: Wetzel, R. G. and Gopal, B. (eds), Limnology in Developing Countries. 3, 1-34.

Gao, C., Q. Lin, \& K. Bao, 2014. Historical variation and recent ecological risk of heavy metals in wetland sediments along Wusuli River, Northeast China. Enviro Earth Sci. DOI 10.1007/s12665-0143334-2.

Garnier, J., G. Billen, S. Even, H. Etcheber, \& P. Servais, 2008. Organic matter dynamics and budgets in the maximum turbidity zone of the Seine Estuary, France.Estuarine, Coastal and Shelf Sciences, 77: 150-162.

Graney, J., K. Salvage, \& W. Zhu, 2008. A Watershed-Based Approach to Environmental Education Integrating Ecology, Hydrology, and Geochimistry.Contemporary Water Research \& Education. 139, 22-28.

Grimes, S., Z. Boutiba, A. Boukalem, M. Bouderbala, B. Boudjellal, S. Boumaza, M. Boutiba, A. Guedioura, A. Hafferssas, F. Hemida, N. Kaidi, H. Khelifi, F. Kerzabi, A. Merzoug, A. Nouar, B. Sellali, H. Sellali-Merabtine, R. Semroud, H. Seridi, M.Z. Taleb, \& T. Touhria, 2003.Biodiversité Marine et Littorale Algérienne. Laboratoire Réseau de Surveillance Environnementale. Université d'Es Senia, Oran, ISBN Nº 9961-9547-O-X. 
Hamaidi-Chergui, F., M.B. Errahmani, F. Benouaklil, \& S.M. Hamaidi, 2013. Preliminary Study on Physico-Chemical Parameters and Phytoplankton of Chiffa River, Blida-Algeria. Journal of Ecosystems, 1-9.

Huang, H., \& J. Lu, 2014. Identification of river xater pollution characteristics based on projection pursuit and factor analysis. Environmental Earth Sciences 72, 3409-3417.

Kies, F., \& N. Taibi, 2011. Influences de la rivière Chéliff sur l'écosystème marin dans la zone de l'embouchure - wilaya de Mostaganem. Editions Universitaires Européennes-EUE. ISBN: 978-613-158966-9.

Kies, F., K. Mezali, \& D. Soualili, 2012. Modélisation sous R de la pêcherie de Mostaganem et des flux de nutriments (N, P, Si) de la rivière Chéliff (Algérie). Editions Universitaires Européennes-EUE. ISBN: 978-3-8381-8346-6.

Kies, F., \& A. Kerfouf, 2014a. Impact of climate change on the West coast of Algeria: Gulf of Oran, Arzew and Mostaganem. Sustainability, Agri, Food and Environmental Research. 2(3): 1-15.

Kies, F., \& A. Kerfouf, 2014b.Physico-chemical characterization of surface waters of the west coast of Algeria: Bay of Mostaganem and Cheliff estuary. Sustainability, Agri, Food and Environmental Research. 2(4): 1-10.

Le Thi, P.Q., G. Billen, J. Garnier, S. Théry, D. Ruelland, X.A. Nghiem, \& V.M. Chau, 2010. Nutrients (N, P, Si) transferts in the subtropical Red River system (China and Vietnam): modelling and budget of nutrients sources and sinks. Journal of Asian Earth Sciences 37, 259-274.

Panday, M., S. Tripathi, A.K. Panday, \& B.D. Tripathi, 2013. Risk assessment of metal species in sediments of the River Ganga. Catena. 122, 140-149.

Persson, P., 1976. La pollution des eaux continentales. Incidence sur les biocénoses aquatiques, Bordas, Paris.

Ramade, F., 2000. Dictionnaire encyclopédique des pollutions. Les polluants. De l'environnement à l'homme, Ediscience International, Paris.

Rodier, J., 1996. L'analyse de l'eau. Eaux naturelles. Eaux résiduaires. Eaux de mer, 8 ème édition, Dunod, Paris.

Rusanov, A.G., \& E.V. Stanislavskaya, 2009. River Pollution in Ladoga Basin: Estimation Based on Diatom Index. Water Ressources. 38: 95-106 .

Shekhar-Shashi, T.R., B.R. Kiran, E.T. Puttaiah, Y. Shivaraj, \& K,M. Mahadeven, 2008. Phytoplankton as index of water quality with reference to industrial pollution.Journal of Environmental Biology. 29: 233-236

Sigg, L., P. Behra W. Stumm, 2000.Chimie des milieux aquatiques. Chimie des milieux naturels et des interfaces dans l'environnement, $3^{\text {ème }}$ édition, Dunod, Paris.

Wang, Y.B., C.W. Liu, P.Y. Liao, \& J.J. Lee, 2013. Spatial pattern assessment of river water quality: implications of reducing the number of monitoring stations and chemical parameters. Environmental Monitoring Assessment. DOI 10.1007/s10661-013-3492-9. 
Sustainability, Agri, Food and Environmental Research 3(1), 2015: 1-16 ISSN: 0719-3726

Woodbury P.B., W. Robert, W., G. Howerth., \& G. Steinhart, 2008. Understanding Nutrient Cycling and Sediment Sources in the upper Susquehanna River Basin.Contemporary Water Research \& Education. 139, 7-14. 